\title{
Hubungan Lingkungan Belajar dan Disiplin Belajar Dengan Hasil Belajar Siswa Mata Pelajaran Instalasi Penerangan Listrik Program Keahlian Teknik Instalasi Tenaga Listrik Kelas XII SMK Karya Guna Jakarta
}

\author{
Sarah Maulidya Cahyani ${ }^{1}$, Soeprijanto ${ }^{2}$, Faried Wadjdi ${ }^{3}$. \\ ${ }^{123}$ S1 Pendidikan Teknik Elektro, Fakultas Teknik, Universitas Negeri Jakarta \\ ${ }^{1}$ Email: maulidyasarah@gmail.com ; soeprijanto@unj.ac.id ; faried@unj.ac.id
}

\begin{abstract}
This research was to aimed at finding out the relationships between environment of study and discipline of study towards student study results of electricity lighting installation subject an expertise program of electricity power installation technique class XII at SMK Karya Guna Jakarta. The population in this study were students of class XII TITL at SMK Karya Guna Jakarta as many as 31 people. Data collection methods for family environment variables and learning independence using questionnaire models with Likert Scale, while for the variable learning achievement of productive subjects using the method of documentation in the form of pure value Mid-Term Exams. The results showed that the hypothesis test with a significance level of 5\% obtained $r_{\text {count }}=0,780$ and value of rtable $=0,355$ where $r_{\text {count }}>$ rtable shows that there is a relationship between variables, then the value of $F_{\text {count }}=21,75$ and Ftable $=3.33$ where $F_{\text {count }}>$ Ftable shows that there is a significance between variables and a determination value of 0,505 which shows the environment of study and discipline of study that have the same relationship to student study results.
\end{abstract}

Keywords: Environment of study, Discipline of study, Student Study Results Electrical Lighting Installation Subject.

\section{ABSTRACT}

Tujuan dari penelitian ini adalah untuk mengetahui hubungan lingkungan belajar dan disiplin belajar dengan hasil belajar siswa mata pelajaran instalasi penerangan listrik. Pada penelitian ini menggunakan metode ex post facto yang bersifat deskriptif korelatif dengan pendekatan kuantitatif. Populasi dalam penelitian ini adalah siswa/i kelas XII TITL di SMK Karya Guna Jakarta sebanyak 31 orang. Metode pengambilan data untuk variabel lingkungan belajar dan disiplin belajar menggunakan kuesioner model angket dengan Skala Likert, sedangkan untuk variabel hasil belajar mata pelajaran instalasi penerangan listrik menggunakan metode dokumentasi berupa nilai Ujian Tengah Semester. Hasil perhitungan menunjukkan bahwa uji hipotesis dengan taraf signifikan $5 \%$ di peroleh nilai rhitung $=0,780$ dan nilai rtabel $=0,355$ dimana rhitung $>$ rtabel menunjukkan bahwa terdapat hubungan antar variabel, kemudian nilai Fhitung $=21,75$ dan Ftabel $=3,33$ dimana Fhitung > Ftabel menunjukkan bahwa terdapat signifikansi antar variabel dan nilai determinasi sebesar 0,505 yang menunjukkan bahwa lingkungan belajar dan disiplin belajar secara bersama-sama memiliki pengaruh sebesar $61 \%$ terhadap hasil belajar.

Kata Kunci : Lingkungan Belajar, Disiplin Belajar, Hasil Belajar Mata Pelajaran Instalasi Penerangan Listrik

\section{PENDAHULUAN}

Pendidikan di Indonesia ada tiga macam, yaitu pendidikan formal, pendidikan informal, dan pendidikan nonformal. Pendidikan yang banyak dipilih di Indonesia adalah pendidikan formal. Dimana pendidikan tersebut berjenjang, mulai dari pendidikan usia dini, pendidikan dasar, pendidikan menengah, dan pendidikan tinggi. Pendidikan menengah salah satunya adalah Sekolah Menengah Kejuruan (SMK). Sekolah Menengah Kejuruan (SMK) menjadi suatu terobosan dalam menciptakan lulusan sekolah menengah dengan keterampilan dan keahlian yang mumpuni untuk dapat terjun langsung dalam dunia kerja tanpa menjalani pendidikan formal tingkat pendidikan tinggi. Sejalan dengan hal tersebut peserta didik SMK dibekali dengan keterampilan dan pengetahuan sesuai dengan jurusan masing-masing, antara lain: mesin,listrik,otomotif,dan lain-lain. Mata pelajaran produkif pada pembelajaran SMK sudah seharusnya menjadi perhatian karena menjadi salah satu penentu kualitas keterampilan pada peserta didik SMK, salah satunya mata pelajaran Instalasi Penerangan Listrik pada program keahlian teknik instalasi tenaga listrik. Hasil belajar peserta didik tercermin dari hasil evaluasi, hasil ulangan dan hasil ujian praktek yang dilakukan peserta didik, didalamnya mencakup aspek kognitif (pemahaman dan intelektual), afektif (sikap dan nilai), dan psikomotorik (keterampilan) setelah peserta didik menerima pembelajaran. Menurut Dalyono (2010) mengemukakan bahwa berhasil 
atau tidaknya seseorang dalam belajar disebabkan dua faktor yaitu faktor internal (berasal dari dalam diri orang yang belajar) meliputi: kesehatan,intelegensi dan bakat,minat dan motivasi, disiplin. Faktor eksternal (berasal dari luar diri yang belajar yang meliputi: keluarga,sekolah, dan masyarakat.

Salah satu faktor yang mempengaruhi hasil belajar peserta didik adalah lingkungan. Pendidikan sebagai usaha yang disengaja dan terencana untuk membantu potensi dan kemampuan anak tidak hanya menjadi tanggungjawab diri sendiri saja, melainkan juga orang tua, lingkungan sekolah, dan lingkungan masyarakat. Lingkungan keluarga bisa memberikan pengaruh positif terhadap aktivitas belajar peserta didik apabila keadaan keluarga cukup harmonis, kondisi ekonomi berkecukupan. Sedangkan lingkungan sekolah, apabila lingkungan sekolahnya berkualitas dimana peserta didik banyak yang mencapai hasil belajarnya, tentu akan memberikan pengaruh kepada peserta didik untuk belajar yang baik dan memacu peserta didik untuk bersaing dalam meraih hasil belajar. Disiplin belajar peserta didik yang baik atau dapat dikatakan tinggi akan dapat mendorong peserta didik meraih hasil belajar tinggi pula. Namun kenyataannya, tingkat disiplin belajar peserta didik di sekolah antara peserta didik yang satu dengan yang lain berbeda. Dikarenakan adanya hubungan lingkungan keluarga, sekolah, dan masyarakat yang berbeda- beda pula.

Tujuan penelitian yang untuk mengetahui hubungan lingkungan belajar dan disiplin belajar dengan hasil belajar siswa mata pelajaran Instalasi Penerangan Listrik Program Keahlian Teknik Instalasi Tenaga Listrik Kelas XII SMK Karya Guna Jakarta.

Berdasarkan latar belakang identifikasi masalah di atas, maka peneliti membatasi masalah penelitian ini yaitu terhadap lingkungan belajar, disiplin belajar, dan hasil belajar siswa mata pelajaran Instalasi Penerangan Listrik Program Keahlian Teknik Instalasi Tenaga Listrik Kelas XII SMK Karya Guna Jakarta.

\section{METODELOGI PENELITIAN}

Tempat penelitian dilaksanakan di SMK Karya Guna Jakarta Jurusan Teknik Instalasi Tenaga Listrik kelas $X$. Waktu penelitian dilakukan dari tanggal 12 Okober 2019 - 15 Desember 2019 pada semester ganjil.

Pada penelitian ini menggunakan metode ex post facto yang bersifat deskriptif korelatif dengan pendekatan kuantitatif. Penelitian ex post facto adalah sebuah penelitian yang bertujuan untuk mengamati fenomena alamiah untuk mengungkapkan fakta yang ada tanpa melakukan manipulasi variabel bebas. Menurut Suharsimi Arikunto (2009: 247) menegaskan bahwa penelitian ini bersifat deskriptif korelasional karena merupakan penelitian yang dimaksudkan untuk mengumpulkan informasi mengenai ada tidaknya hubungan antara dua atau beberapa variabel. Paradigma atau model hubungan antara hubungan variabel X1 dan X2, dengan Y dapat dilihat pada gambar 1.

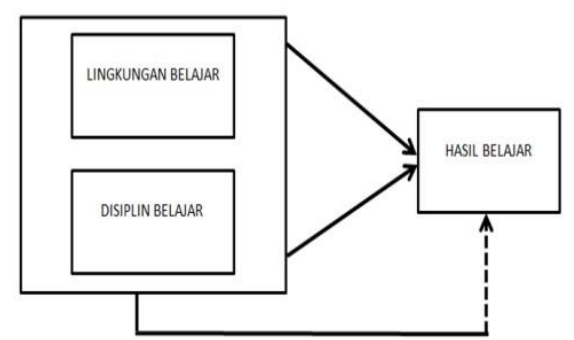

\section{Gambar 1. Hubungan X1 dan X2 dengan $Y$} Keterangan :

$\mathrm{X}_{1} \quad$ : Lingkungan Belajar $\left(\mathrm{X}_{1}\right)$

$\mathrm{X}_{2} \quad$ : Disiplin Belajar $\left(\mathrm{X}_{2}\right)$

$\mathrm{Y} \quad$ : Hasil Belajar (Y)

Populasi dalam penelitian ini adalah siswa/i kelas XII TITL SMK Karya Guna Jakarta sebanyak 31 orang. Teknik sampling yang digunakan adalah teknik sampling jenuh atau semua populasi dijadikan sebagai sampel. Teknik pengumpulan data untuk variabel lingkungan belajar, disiplin belajar menggunakan kuesioner (angket). Sedangkan variabel hasil belajar siswa mata pelajaran instalasi penerangan listrik menggunakan metode dokumentasi berupa nilai Ulangan Tengah Semester. Instrumen penelitian diuji validitasnya menggunakan rumus rumus korelasi Pearson's Product Moment. Pengujian reliablitas pada instrumen kuesioner (angket) menggunakan koefisien reliabilitas Alfa Cronbach. Teknik analisis data yang digunakan dalam penelitian ini adalah statistik deskriptif korelatif. Pengujian hipotesis dalam penelitian ini menggunakan nilai $\alpha=0,05$, namun sebelum melakukan uji hipotesis, terlebih 
dahulu dilakukan uji normalitas menggunakan Chi Kuadrat dan linearitas. Lalu setelah melakukan uji normalitas dan uji linearitas, maka dilakukan uji hipotesis menggunakan analisis korelasi Pearson's Product Moment. Tahapan penelitian meliputi beberapa hal yaitu: 1) Mengidentifikasi masalah, 2) Membuat hipotesis, 3) Studi literature, 4) Mengidentifikasi dan menamai variabel, 5) Membuat defisini operasional, 6) Memvalidasi dan mengontrol variabel instrumen, 7) Menyusun desain penelitian, 8) Mengindentifikasi dan menyusun variabel instrumen dan pengukuran, 9) Membuat jadwal survey penelitian, 10) Melakukan analisa statistik, 11) Menggunakan komputer untuk analisis data, dan 12) Menulis laporan hasil penelitian

\section{HASIL DAN PEMBAHASAN Hasil Belajar}

Berikut adalah distribusi frekuensi data hasil belajar yang dapat dilihat pada tabel 1 .

Tabel 1. Distribusi Frekuensi Data Hasil Belajar

\begin{tabular}{cccc}
\hline No. & Kelas Interval & Tepi Kelas & $\mathrm{Fa}$ \\
\hline 1. & $79-80$ & $78,5-80,5$ & 1 \\
2. & $81-82$ & $80,5-82,5$ & 3 \\
3. & $83-84$ & $82,5-84,5$ & 5 \\
4. & $85-86$ & $84,5-86,5$ & 7 \\
5. & $87-88$ & $86,5-88,5$ & 6 \\
6. & $89-90$ & $88,5-90,5$ & 9 \\
\hline \multicolumn{3}{c}{ Jumlah } \\
\hline
\end{tabular}

Berdasarkan tabel 1. diketahui bahwa variabel hasil belajar memiliki frekuensi tertinggi yaitu sebanyak 9 siswa yang memiliki nilai pada rentang 89-90, sedangkan frekuensi terendah yakni sebanyak 1 siswa yang terletak pada interval kelas ke 1 yakni antara 79-80 dan interval kelas ke 2 yakni sebanyak 3 siswa antara 81-82. Kemudian hasil lainnya yaitu sebanyak 5 siswa memiliki nilai pada rentang 83-84, lalu 7 siswa yang memiliki nilai pada rentang 85-86, lalu 6 siswa yang memiliki rentang nilai $87-88$.

\section{Lingkungan Belajar}

Berikut adalah distribusi frekuensi data lingkungan belajar yang dapat dilihat pada tabel Tabel 2. Distribusi Frekuensi Data Lingkungan

$$
\text { Belajar }
$$

No. Kelas Interval Tepi Kelas $\quad \mathrm{Fa}$

\begin{tabular}{llll}
\hline 1. & $79-80$ & $78,5-80,5$ & 1 \\
2. & $81-82$ & $80,5-82,5$ & 3 \\
3. & $83-84$ & $82,5-84,5$ & 4 \\
4. & $85-86$ & $84,5-86,5$ & 7 \\
5. & $87-88$ & $86,5-88,5$ & 7 \\
6. & $89-90$ & $88,5-90,5$ & 9 \\
\hline & Jumlah & \multicolumn{2}{c}{31} \\
\hline
\end{tabular}

Berdasarkan tabel 2. diketahui bahwa variabel lingkungan belajar memiliki frekuensi tertinggi yaitu sebanyak 9 siswa pada rentang 89- 90, sedangkan frekuensi Berdasarkan tabel 2 . diketahui bahwa variabel lingkungan belajar memiliki frekuensi tertinggi yaitu sebanyak 9 siswa pada rentang 89-90, sedangkan frekuensi terendah yakni sebanyak 1 siswa yang terletak pada interval kelas ke 1 yakni antara 79-80. Kemudian hasil lainnya yaitu rentang 81- 82 memiliki frekuensi 3 siswa, lalu pada rentang 83- 84 memiliki frekuensi 4 siswa, lalu rentang 85- 86 memiliki frekuensi 7 siswa, lalu 7 siswa terletak pada rentang nilai 89-90.

\section{Disiplin Belajar}

Berikut adalah distribusi frekuensi data disiplin belajar yang dapat dilihat pada tabel 3 .

Tabel 3. Distribusi Frekuensi Data Disiplin

\begin{tabular}{llcc}
\multicolumn{3}{c}{ Belajar } \\
\hline No. & $\begin{array}{l}\text { Kelas } \\
\text { Interval }\end{array}$ & Tepi Kelas & $\mathrm{Fa}$ \\
\hline 1. & $79-80$ & $78,5-80,5$ & 1 \\
2. & $81-82$ & $80,5-82,5$ & 3 \\
3. & $83-84$ & $82,5-84,5$ & 5 \\
4. & $85-86$ & $84,5-86,5$ & 8 \\
5. & $87-88$ & $86,5-88,5$ & 7 \\
6. & $89-90$ & $88,5-90,5$ & 7 \\
\hline \multicolumn{3}{c}{ Jumlah } & \multicolumn{2}{c}{31} \\
\hline
\end{tabular}

Berdasarkan tabel 3. diketahui bahwa variabel disiplin belajar memiliki frekuensi tertinggi yaitu antara 85-86 memiliki frekuensi sebanyak 8 siswa, sedangkan frekuensi terendah yang terletak pada interval kelas ke 1 yakni antara 79-80 memiliki frekuensi sebanyak 1 siswa. Kemudian hasil lainnya yaitu pada rentang 8182 memiliki frekuensi 3 siswa, lalu pada rentang 83-84 memiliki frekuensi 5 siswa, lalu pada rentang 87-88 memiliki frekuensi 7 siswa, lalu rentang 89-90 memiliki frekuensi 7 siswa.

\section{Uji Normalitas}


Berikut adalah perhitungan uji normalitas lingkungan belajar, disiplin belajar, dan hasil belajar yang dapat dilihat pada tabel 4 .

Tabel 4. Uji Normalitas Lingkungan Belajar, Disiplin Belajar dan Hasil Belajar

\begin{tabular}{ccccc}
\hline $\begin{array}{c}\text { Uji } \\
\text { Normalitas }\end{array}$ & Dk & $\begin{array}{c}\chi^{\mathbf{2}} \\
\text { tabel }\end{array}$ & $\chi^{\mathbf{2}}$ hitung & Ket \\
\hline $\begin{array}{c}\text { Lingkungan } \\
\text { Belajar }\end{array}$ & 5 & 11,07 & 9,757 & Normal \\
$\begin{array}{c}\text { Disiplin } \\
\text { Belajar }\end{array}$ & 5 & 11,07 & 8,1453 & Normal \\
$\begin{array}{c}\text { Hasil } \\
\text { Belajar }\end{array}$ & 5 & 11,07 & 9,473 & Normal \\
\hline
\end{tabular}

Pada tabel 4. Untuk variabel lingkungan belajar $\mathrm{X}_{\text {hitung }}^{2}=9,757$, sedangkan $\mathrm{X}_{\text {tabel }}=11,070$, untuk $\alpha=0,05$ dan $\mathrm{dk}=5$. Karena $\mathrm{X}^{2}$ hitung $\leq$ $\mathrm{X}_{\text {tabel }}^{2}$ maka dapat disimpulkan bahwa penyebaran data pada variabel lingkungan belajar berdistribusi normal. Untuk variabel disiplin belajar $X^{2}$ hitung $=8,1453$, sedangkan $\mathrm{X}_{\text {tabel }}^{2}=11,070$, untuk $\alpha=0,05$ dan $\mathrm{dk}=5$. Karena $X^{2}$ hitung $\leq X_{\text {tabel }}^{2}$ maka dapat disimpulkan bahwa penyebaran data pada variabel disiplin belajar berdistribusi normal. Untuk variabel hasil belajar instalasi penerangan listrik $X_{\text {hitung }}^{2}=9,473$, sedangkan $\mathrm{X}_{\text {tabel }}^{2}=11,070$, untuk $\alpha=0,05 \mathrm{dan} \mathrm{dk}=5$. Karena $X^{2}{ }_{\text {hitung }} \leq X_{\text {tabel }}^{2}$ maka dapat disimpulkan bahwa penyebaran data pada variabel hasil belajar instalasi penerangan listrik berdistribusi normal.

\section{Uji Linearitas}

Berikut adalah perhitungan uji linearitas lingkungan belajar dengan hasil belajar yang dapat dilihat pada tabel 5 .

Tabel 5. Uji Linearitas Lingkungan Belajar

\begin{tabular}{|c|c|c|c|c|c|}
\hline $\begin{array}{c}\text { Uji } \\
\text { Linieritas }\end{array}$ & $\mathrm{n}$ & Dk & $\begin{array}{c}\mathbf{F} \\
\text { hitung }\end{array}$ & $\begin{array}{c}\mathbf{F} \\
\text { Table }\end{array}$ & Ket \\
\hline $\begin{array}{c}\text { Lingkungan } \\
\text { Belajar } \\
\text { dengan } \\
\text { Hasil } \\
\text { Belaiar }\end{array}$ & 31 & $\begin{array}{l}29 \& \\
31\end{array}$ & $\begin{array}{l}41,07 \\
9\end{array}$ & 3,33 & Linier \\
\hline
\end{tabular}

Berdasarkan hasil analisis varians (Anava) pada tabel 5. diketahui nilai variabel lingkungan belajar dengan hasil belajar yaitu $\mathrm{F}_{\text {hitung }}=$ 41,079 dengan derajat kebebasan (dk) pembilang sebesar $28 \mathrm{dan} \mathrm{dk}$ penyebut sebesar 31 dan taraf signifikansi $\alpha=5 \%$, maka diperoleh $F_{\text {tabel }}=3,33$. Dilihat dari kriteria pengujian yang digunakan, maka diperoleh hasil pengujian hipotesis tersebut menunjukkan $\mathrm{F}_{\text {hitung }}<\mathrm{F}_{\text {tabel }}$ maka $\mathrm{H}_{0}$ diterima yang berarti terdapat persamaan linier antara variabel lingkungan belajar dengan hasil belajar

Selanjutnya adalah perhitungan uji linearitas disiplin belajar dengan hasil belajar yang dapat dilihat pada tabel 6

Tabel 6. Uji Linearitas Disiplin Belajar dengan

\begin{tabular}{cccccc}
\multicolumn{6}{c}{ Hasil Belajar } \\
\hline $\begin{array}{c}\text { Uji } \\
\text { Linieritas }\end{array}$ & $\mathbf{n}$ & $\mathbf{D k}$ & $\mathbf{F}_{\text {hitung }}$ & $\mathbf{F}_{\text {tabel }}$ & Ket \\
\hline $\begin{array}{c}\text { Disiplin } \\
\text { Belajar }\end{array}$ & & $28 \&$ & & & \\
dengan & 31 & 31 & 44,970 & 3,33 & Linier \\
Hasil & & & & & \\
Belajar & & & & & \\
\hline
\end{tabular}

\section{Uji Hipotesis}

Berikut adalah perhitungan uji hipotesis korelasi pearson product moment lingkungan belajar dengan hasil belajar dapat dilihat pada tabel 7 dan tabel 8 untuk Uji Signifikansi Korelasi

Tabel 7. Uji Korelasi Pearson Product Moment

\begin{tabular}{ccccc}
\hline $\mathbf{N}$ & $\mathbf{a}$ & $\mathbf{r}_{\text {hitung }}$ & $\mathbf{r}_{\text {tabel }}$ & Ket \\
\hline 31 & 0,05 & 0,766 & 0,355 & Ha Diterima
\end{tabular}

Tabel 8. Uji Signifikansi Korelasi (Uji t)

\begin{tabular}{ccccc}
\hline $\mathbf{N}$ & $\mathbf{a}$ & $\mathbf{t}_{\text {hitung }}$ & $\mathbf{t}_{\text {tabel }}$ & Ket \\
\hline 31 & 0,05 & 6,4168 & 2,0484 & $\begin{array}{c}\mathrm{Ha} \\
\text { Diterima }\end{array}$ \\
\hline
\end{tabular}

Selanjutnya adalah perhitungan uji Hipotesis korelasi pearson product moment disiplin belajar dengan hasil belajar dapat dilihat pada tabel 9. dan tabel 10. untuk Uji Signifikansi Korelasi.

Tabel 9. Uji Korelasi Pearson Product Moment

\begin{tabular}{ccccc}
$\mathbf{N}$ & $\mathbf{a}$ & $\mathbf{r}_{\text {hitung }}$ & $\mathbf{r}_{\text {tabel }}$ & Ket \\
\hline 31 & 0,05 & 0,780 & 0,355 & $\begin{array}{c}\text { Ha } \\
\text { Diterima }\end{array}$ \\
\hline \multicolumn{4}{c}{ Tabel 10. Uji } & Signifikansi Korelasi (Uji t) \\
\hline $\mathbf{N}$ & $\mathbf{A}$ & $\mathbf{t}_{\text {hitung }}$ & $\mathbf{t}_{\text {tabel }}$ & Ket \\
\hline 31 & 0,05 & 6,7123 & 2,0484 & $\begin{array}{c}\text { Ha } \\
\text { Diterima }\end{array}$ \\
\hline
\end{tabular}

Selanjutnya adalah perhitungan uji Hipotesis Korelasi Pearson Product Moment lingkungan belajar dengan hasil belajar dilihar pada tabel 11 dan tabel 12 Uji Signifikan Korelasi. 
Tabel 11. Uji Korelasi Pearson Product Moment

\begin{tabular}{ccccc}
\hline $\mathbf{N}$ & $\mathbf{A}$ & $\mathbf{r}_{\text {hitung }}$ & $\mathbf{r}_{\text {tabel }}$ & Ket \\
\hline 31 & 0,05 & 0,780 & 0,355 & $\begin{array}{c}\text { Ha } \\
\text { Diterima }\end{array}$
\end{tabular}

Tabel 12. Uji Signifikansi Korelasi (Uji F)

\begin{tabular}{ccccc}
$\mathbf{N}$ & $\mathbf{A}$ & $\mathbf{F}_{\text {hitung }}$ & $\mathbf{F}_{\text {tabel }}$ & Ket \\
\hline 31 & 0,05 & 21,750 & 3,33 & Ha \\
& & & & Diterima \\
\hline
\end{tabular}

\section{KESIMPULAN DAN SARAN KESIMPULAN}

Berdasarkan hasil penelitian dan pembahasan maka dapat disimpulkan bahwa:

1. Dari penelitian dan pengolahan data yang sudah dilakukan, menyatakan bahwa terdapat hubungan antara lingkungan belajar dengan hasil belajar instalasi penerangan listrik siswa kelas XII TITL SMK Karya Guna Jakarta. Berdasarkan hasil perhitungan koefisien product moment dan uji- $\mathrm{t}$ menunjukkan nilai $\mathrm{r}_{\mathrm{yx} 1}=0,766$ yang termasuk dalam kategori tinggi pada tabel korelasi dan thitung $=6,41689$ nilai ini lebih besar dari ttabel $=2,04841$. Maka dapat dikatakan bahwa kedua variabel tersebut mempunyai hubungan positif dan signifikan.

2. Dari penelitian dan pengolahan data yang sudah dilakukan, menyatakan bahwa terdapat hubungan antara disiplin belajar dengan hasil belajar instalasi penerangan listrik siswa kelas XII TITL SMK Karya Guna Jakarta. Berdasarkan hasil perhitungan koefisien product moment dan uji-t menunjukkan nilai $\mathrm{r}_{\mathrm{yx} 2}=0,780$ yang termasuk dalam kategori tinggi pada tabel korelasi dan $t_{\text {hitung }}=6,71231$ nilai ini lebih besar dari $t_{\text {tabel }}=2$ 2,04841. Maka dapat dikatakan bahwa kedua variabel tersebut mempunyai hubungan positif dan signifikan.

3. Dari penelitian dan pengolahan data yang sudah dilakukan, menyatakan bahwa terdapat hubungan antara lingkungan belajar dan disiplin belajar dengan hasil belajar instalasi penerangan listrik siswa kelas XII TITL SMK Karya Guna Jakarta. Berdasarkan hasil perhitungan koefisien product moment dan uji-F menunjukkan nilai $r_{\mathrm{yx} 1,2}=0,780$ yang termasuk dalam kategori tinggi pada tabel korelasi dan $F_{\text {hitung }}=$ 21,75077 nilai ini lebih besar dari $\mathrm{F}_{\text {tabel }}=3,33$. Maka dapat dikatakan bahwa variabel bebas secara bersama-sama mempunyai hubungan yang positif dan signifikan dengan hasil belajar instalasi penerangan listrik.

\section{Saran}

Berdasarkan hasil penelitian dalam pembahasan dan kesimpulan yang didapat, lingkungan belajar memiliki kaitan dengan disiplin belajar siswa untuk memperoleh hasil belajar yang tinggi. Maka dari itu peneliti memiliki saran sebagai berikut:

1. Siswa kelas XII TITL SMK Karya Guna Jakarta, diharapkan mampu menciptakan interaksi dan pembinaan hubungan baik dengan orang tua serta anggota keluarga di rumah, siswa lainnya dan para guru di sekolah. Tindakan tersebut bertujuan agar siswa dapat memahami lingkungan belajarnya guna mendapatkan hasil belajar yang maksimal, sebab dengan terciptanya lingkungan belajar yang baik secara simultan mempengaruhi proses pengambilan keputusan dan penerimaan belajar siswa secara baik, sehingga berpengaruh pada hasil belajar siswa yang baik.

2. Mengingat lama pendidikan di sekolah tidak selama di rumah bersama dengan orang tua, maka perlunya kerjasama antara orang tua dan guru di sekolah untuk menjadikan atau memberikan sikap teladan kedisiplinan kepada siswa terutama disiplin belajar, sehingga diharapkan dengan adanya kerjasama tersebut dapat meningkatkan disiplin belajar siswa baik di rumah maupun di sekolah, dan target pendidikan 
siswa pun dapat tercapai yakni hasil belajar yang maksimal.

3. Kepala Jurusan Teknik Instalasi Tenaga Listrik SMK Karya Guna Jakarta, diharapkan mampu memberikan bimbingan kepada siswanya untuk dapat mempertahankan lingkungan belajar yang baik serta selalu memberikan sikap teladan kedisiplinan terutama mengenai displin belajar, kedua hal tersebut bertujuan agar para siswa mendapatkan hasil belajar yang maksimal.

\section{DAFTAR PUSTAKA}

[1] Dimyati dan Mudjiono. 2009. Belajar dan Pembelajaran. Jakarta: PT. Rineka Cipta.

[2] B uno, Hamzah. 2006. Orientasi Baru dalam Psikologi Pembelajaran. Jakarta: PT Bumi Aksara

[3] A.M. Sardiman. 2011. Interaksi dan Motivasi Belajar Mengajar. Jakarta: Rajawali Press.

[4] Syah, Muhibbin. 2009. Psikologi Belajar, Jakarta: PT. Raja Grapindo Persada.

[5] Soedijarto. 1993. Menuju Pendidikan Nasional Yang Relevan Dan Bermutu, Jakarta: Balai Pustaka.

[6] Sudjana. 2001. Metode \& Teknik Pembelajaran Partisipatif. Bandung : Falah Production.

[7] Ngalim Purwanto. 2009. Evaluasi Hasil Belajar. Yogyakarta : Pustaka Pelajar.

[8] Bloom, Benjamin S., etc. 1956. Taxonomy Of Educational Objectives: The Classification of Educational Goals, Handbook I Cognitive Domain. New York : Longmans, Green and Co.

[9] Anderson, Lorin WR. David, Krathwohl. Airasian, Peter W. Kathleen, A. Crvikshank. Richad, E. Paul, R Mayer. Raths, J P. Wittrock, C Marlin. 2000. A Taxonomy For Learning, Teaching and Assesing, (A Revision of Bloom Taxonomy of Educational Objectives, Abridged Edition). Longman: Newyork.
[10] Muhibbin Syah, 2004. Psikologi Pendidikan dengan Pendekatan Baru. Bandung : Remaja Rosda Karya.

[11] Musfiqon, 2012. Pengembangan Media dan Sumber Pelajaran. Jakarta: Prestasi Pustaka

[12] Purwanto, Ngalim. (2006). Psikologi Pendidikan. Bandung: Remaja Rosdakarya..

[13] Djamarah, Syaiful Bahri. 2011. Psikologi Belajar. Jakarta : Rineka Cipta.

[14] Ngalim Purwanto. 2004. Prinsip-Prinsip dan Teknik Evaluasi Pengajaran. Bandung : Rosdakarya.

[15] Kartini Kartono, Patologi Sosial, (Jakarta: CV. Rajawali, 1997).

[16] Slameto. 2003. Belajar dan Faktorfaktor yang Mempengaruhinya. Jakarta: Rineka Cipta.

[17] Imam Supardi. 2003. Lingkungan Hidup dan Kelestariannya. Bandung: PT. Alumni.

[18] Syamsu Yusuf. 2001. Psikologi Perkembangan Anak dan Remaja. Bandung: Remaja Rosdakarya.

[19] Barnett and Casper. 2001. Health Disparities: Linking Biological and Behavorial Mechanisms with Social and Physical Environmenst. Morgantown: Health Sciences Center, West Virginia University.

[20] Ma'sumah, Siti. 2015. Pengaruh Disiplin Belajar Terhadap Prestasi Belajar Siswa Kelas IV Sekolah Dasar Negeri Se-Daerah Binaan II Kecamatan Petanahan Kabupaten Kebumen. (Skripsi S-1 Progdi PGSD). Semarang: Fakultas PGSD.

[21] Arikunto, S. 2010. Prosedur Penelitian Suatu Pendekatan Praktik. Jakarta: Rineka Cipta

[22] Jailani, Pahrul. 2014. Hubungan Antara Disiplin Belajar dan Motivasi Belajar Dengan Hasil Belajar Siswa Kelas VA SD Negeri 03 Kota Bengkulu. Bengkulu: Universitas Bengkulu.

[23] E. Mulyasa. 2009. Praktik Penelitian Tindakan Kelas. Bandung: Rosdakarya.

[24] Arifin, M dan Barnawi. (2012). Strategidan Kebijakan Pembelajaran 
Pendidikan Karakter. Yogjakarta: ARRUZZ MEDIA.

[25] Wibowo (2012). Manajemen Kinerja. Jakarta: raja Grafindo Persada.

[26] Tulus, Tu’u. 2004. Peran Disiplin pada Perilaku dan Prestasi Belajar. Jakarta: Grasindo

[27] Setyaningrum, Istriana. 2011. Hubungan antara Disiplin Belajar dan Motivasi Belajar dengan Hasil Belajar IPA Siswa Kelas V SD Negeri Gugus Lokantara Kecamatan Temanggung Kabupaten

Temanggung Semester 1 Tahun Pelajaran 2011/2012. Skripsi. Universitas Kristen Satya Wacana Salatiga.

[28] Sugiyono. 2004. Metode Penelitian. Bandung: Alfabeta.

[29] Sudjana, Nana. dan Ibrahim, Penelitian dan Penilaian Pendidikan, Bandung: Sinar Baru Algensindo,2007

[30] Sugiyono. (2016). Metode

Penelitian Kuantitatif, Kualitatif dan R\&D. Bandung: PT Alfabet.

[31] Sugiyono. 2010. Metode

$$
\begin{aligned}
& \text { Penelitian } \quad \text { Pendidikan } \\
& \text { Pendekatan }
\end{aligned}
$$

kualitatif, dan R\&D. Bandung: Alfabeta.

[32] Anas Sudijono. (2011). Pengantar Statistik Pendidikan. Jakarta: Rajawali Pers.

[33] Sugiyono (2015). Metode Penelitian Kombinasi (Mix Methods). Bandung: Alfabeta.

[34] Sugiyono. 2011. Metode Penelitian Kuantitatif, Kualitatif dan R\&D. Bandung: Afabeta.

[35] Seniati, L., Yulianto, A., dan Setiadi, B. N. 2005. Psikologi Eksperimen. Jakarta: PT. Indeks. 